\title{
Spring Food Habits of White-tailed Deer in the South Texas Plains
}

\section{JAMES H. EVERITT AND D. LYNN DRAWE}

Highlight: During the spring seasons of 1970 and 1971, rumen analyses were used to determine food preferences of white-tailed deer on the H. B. Zachry Randado Ranch in South Texas. A total of 83 plant taxa were found to be eaten by this deer herd. Forbs comprised an average of $37.1 \%$ by volume of the diet, browse $33.1 \%$, and cacti $17.5 \%$, while grass comprised only $2.5 \%$ volume of the diet. Pricklypear cactus was heavily consumed and comprised an average of $15.4 \%$ of the total diet. Forbs were most heavily utilized in early spring. Perennial species were more prevalent than annuals in the diet: Important differences occurred in the diet between years, between early and late spring, and between the three major range sites on the study area.

Increased emphasis on hunting for recreation has focused attention on improved management of wild life in general, and of deer in particular. Ramsey (1965) emphasized that potential economic returns from deer were greater than from livestock under average prices and adequate deer harvest. Since the white-tailed deer provides a significant amount of recreation to the public and is a source of economic returns to the landowner, a knowledge of the food habits of the white-tailed deer is essential if deer herd management is to improve.

Deer food habits studies have been conducted in many parts of the United States. Atwood (1941) lists more than 600 plants utilized by white-tails in the United States. Because of the variability of plant species from area to area, no

Authors are graduate research assistant and assistant professor of range science, Texas A\&I University, Kingsville.

At present the senior author is agricultural research technician, Earth Resources Satellite Program, Agricultural Research Service, Weslaco, Texas.

Publication costs were defrayed by the Caesar Kleberg Chair in Wildlife Ecology, Texas A\&I University. This paper is part of a thesis presented by the senior author as partial fulfillment of the requirements for the Master of Science Degree at Texas A\&I University. Caesar Kleberg Foundation Scholarship, No. CKF $8440-24$, was granted by Texas A\&I to the senior author for this research.

Manuscript received December 18, 1972. general list of deer food preferences can be made.

Numerous studies have been conducted on the food habits of white-tailed deer in Texas. Hahn (1945), McMahan (1964), and Kelley (1970) found deer in the Edwards Plateau of Central Texas to be primarily browsers, but grasses and forbs were important during spring. Davis (1951) and Davis and Winkler (1968) also found browse to be the major food of whitetailed deer in South Texas; however, forbs were important in spring. Grasses were utilized little and were important only in winter and early spring. Chamrad and Box (1968) conducted a winter and spring food habits study on the Welder Wildlife Refuge in South Texas and found deer to be grazers, with forbs and grasses comprising 90\% of the diet. Drawe (1968) investigated midsummer food habits of deer on the Welder Refuge and found forbs to constitute over $60 \%$ of the diet. Browse accounted for $33 \%$ of the diet, while grass was not significant.

This paper reports the results of a study of the white-tailed deer's spring food habits on the H. B. Zachry Randado Ranch in the western portion of the South Texas Plains. Because of limited time, only spring food habits were studied; diet for the other seasons is being determined by another researcher. The objectives of this study were (1) to determine spring food preference of white-tailed deer on the ranch; (2) to compare food preferences in Spring, 1970, with those of Spring, 1971; (3) to compare early spring with late spring diet; and (4) to determine food preferences on various range sites of the ranch.

\section{Study Area}

The H. B. Zachry Randado Ranch is located approximately 28 miles southwest of Hebbronville and 26 miles northeast of Zapata on the Jim Hogg-Zapata County line. The ranch consists of 7,500 acres of native rangeland enclosed by an 8-foot high, deer-proof fence. This area is included in the South Texas Plains vegetational region (Gould, 1969).

The climate of this area is mild with short winters and relatively warm temperatures throughout the year. Average annual rainfall for Jim Hogg County is 20.78 inches. Heaviest rains occur in May and September, with monthly averages of 2.66 and 3.65 inches, respectively, (Texas Almanac, 1970).

Temperatures are high with a yearly average of $71.3^{\circ} \mathrm{F} .^{1}$ January is the coldest month with an average minimum temperature of $47^{\circ} \mathrm{F}$, while July is warmest with an average maximum of $99^{\circ} \mathrm{F} .{ }^{2}$

The topography of the ranch can be described as flat, but broken by caliche and gravel ridges.

Four major range sites have been named on the ranch in a concurrent research study (Higginbotham, 1972) (Table 1). The first of these is the shallow ridge site associated with Zapata fine

${ }^{1}$ Soil Conservation Service Records, Hebbronville, Texas; unpublished data.

${ }^{2}$ Don Meyer, Climatologist, Hebbronville, Texas; personal communication. 
sandy loam soils. This site is dominated by brushy species with little herbaceous understory. Second is a sandy loam site, associated with McAllen, Garceno, and Brennan fine sandy loam soils. This site is dominated by mesquite, but other species also occur there. Third is the Ramadero site, which supports dense brush and consequently less herbaceous vegetation. It is associated with Ramadero sandy clay loam soils. Fourth is the deep sand site, which is relatively open with an intermixture of brush, grasses, and annual forbs. It is associated with Nueces-Sarita soils.

There are approximately 200 head of cows and calves on the ranch. A threepasture, two-herd, prescription-rotation grazing system is practiced. Cattle are moved approximately every 4 months. Deer have continuous access to all areas occupied by cattle. There is a large population of white-tailed deer on the ranch, estimated by aerial census to be 400 head, or an average of one deer to 19 acres.

\section{Methods}

Food habits were determined by rumen analysis. A total of 62 deer, predominantly does, were randomly collected at 2-to 3 -week intervals from early February through early June of 1970 and 1971. Due to relatively warm winters, spring begins in early February and is marked by the appearance of many species of annual forbs. February 1 through March 31 was designated early spring, while April 1 through June 8 was designated late spring. A total of 23 deer were collected during spring 1970 , while 39 were collected during spring 1971.

Study animals were randomly collected during early morning and late evening feeding hours from various range sites; however, they were grouped into three range sites. Those obtained from the small deep sand site were grouped with those from the large, surrounding sandy loam site because of apparent use of both sites by the animals. Variable numbers of deer were taken at each collection date. A maximum of seven were taken on one date while only two were obtained on another. Plant species composition data for the various range sites were obtained from a concurrent study (Higginbotham, 1972). Species composition of woody plants was determined in that study by using line transects (Canfield, 1941), while the point frame was used to determine herbaceous composition (Tothill and Peterson, 1962).

After collection the entire rumen was removed from each deer and a 1-quart random sample was taken. Samples collected in 1970 were preserved in formalin, while those collected in 1971 were frozen in an attempt to maintain sample quality. Samples were analyzed by the point frame method (Chamrad and Box, 1964). Using this method, both percent volume and percent frequency of occurrence of a species were obtained.

After analysis and identification of rumen samples the species were grouped into five classes: (1) browse, (2) forbs, (3) grass, (4) cacti, and (5) unknown material. Data were summarized and averaged according to forage class, early and late spring, years, and range sites. All data reported are averages for the category indicated.

Since food availability largely determines diet, a means of comparing the two was needed. The preference rating formula described by Chamrad and Box (1968) was employed:

Preference Rating =

$\%$ Frequency of Occurrence $\times \%$ Volume Availability Factor

Percent volume for each species util ized was derived from the percentage of total points contacting that species in the sample. Percent frequency of occurrence was the percentage of deer in which a given plant species was found. The availability factor is a numerical value related to plant abundance on the range, and plant spccics composition data from the range were used in determining it. Numerous scales have been used to classify the abundance of species. Vestal (1943) presented unequal scales for rating species in communities. Due to species diversily on the study area, the following scales were used:

\section{Availability Class}

Availability

Rare $\left(0^{-} .50 \%\right)$

composition)

Occasional $(0.51 \%-2.50 \%$

composition)

Frequent (2.51-7.50\%

composition)

Abundant $(>7.50 \%$

composition)

Factor

Data were subjected to analysis of variance. All statistical comparisons presented are significant at the .05 level.

\section{Results and Discussion}

\section{Overall Food Preferences}

Based on analyses of 62 rumens, average volume percentages for the various forage classes were $33.1 \%$ browse, $37.1 \%$ forbs, $2.5 \%$ grass, $17.5 \%$ cacti, and $9.4 \%$ unknown. Percentages of browse and forbs were significantly higher than those of other classes.

A total of 83 different plant taxa were identified (Table 2). Of this total there were 51 forbs, 25 browse species, 5 grasses, and 2 cacti. Perennials were more prevalent than annuals in the diet. A large
Table 1. Major plant species of the Zachry Ranch and range sites on which they dominate.

\begin{tabular}{|c|c|}
\hline Species $^{1}$ & Site $^{2}$ \\
\hline \multicolumn{2}{|l|}{ Woody } \\
\hline Acacia berlandieri & 1 \\
\hline A. greggï & 2,4 \\
\hline A. rigidula & 1 \\
\hline Aloysia lycioides & 3 \\
\hline Celt is pallida & $2,3,4$ \\
\hline Colubrina texensis & 3 \\
\hline Condalia obtusifolia & 2,3 \\
\hline Larrea divaricata & 1 \\
\hline Leucophyllum frutescens & 1 \\
\hline Lycium berlandieri & 4 \\
\hline Porlieria angustifolia & 2,3 \\
\hline Prosopis glandulosa & $2,3,4$ \\
\hline Schaefferia cuneifolia & 2 \\
\hline Zanthoxylum fagara & 3 \\
\hline \multicolumn{2}{|l|}{ Cacti } \\
\hline Opuntia leptocaulis & 2,4 \\
\hline O. lindheimeri & 2,4 \\
\hline \multicolumn{2}{|l|}{ Grasses } \\
\hline Aristida purpurea & 4 \\
\hline Bouteloua trifida & 1,2 \\
\hline Brachiaria ciliatissima & 4 \\
\hline Buchloe dactyloides & 2 \\
\hline Cenchrus ciliaris & 2 \\
\hline Cenchrus incertus & 4 \\
\hline Chloris cucullata & 2,3 \\
\hline Digitaria californica & 3 \\
\hline Eragrost is oxylepis & 4 \\
\hline Pappophorum bicolor & 2 \\
\hline Paspalum setaceum & 4 \\
\hline Setaria texana & 1,3 \\
\hline S. firmula & 1,3 \\
\hline S. leucopila & 2,3 \\
\hline Trichloris pluriflora & 3 \\
\hline \multicolumn{2}{|l|}{ Forbs } \\
\hline Aphanostephus riddellii & $1,2,3$ \\
\hline Dyssodia tenuiloba & 1 \\
\hline Parthenium confertum & $1,2,3$ \\
\hline Physalis viscosa & $2,3,4$ \\
\hline Ambrosia psilostachya & 3 \\
\hline A phanostephus kidderi & 4 \\
\hline Callirhoe involucrata & 4 \\
\hline Cynanchum barbigerum & 4 \\
\hline
\end{tabular}

number of annual forbs were recorded, but few of these contributed high volumes to the diet. Grass was utilized only to a minor extent. These data indicate that, where given a choice, the white-tail will select a herbaceous diet. The Zachry Ranch offers this choice, i.e. there is a good intermixture of brushland and grassland, and the ranges have been placed in fair condition.

From this variety of species, however, there were 10 major taxa that made up $53 \%$ of the diet. Among these were three forbs, six browse species, and one cactus. This narrows the number of so called "major" species, but it should be emphasized that the remaining 73 "minor" species made up almost $50 \%$ of the volume of the diet. 
The three major forbs included perennial lazy daisy (Aphanostephus riddellii), groundcherry (Physalis viscosa var. cinerascens), and winecup (Callirhoe involucrata). The most heavily utilized of these was perennial lazy daisy.

Among the six browse species were mesquite (Prosopis glandulosa), granjeno (Celtis pallida), lotebush (Condalia obtusifolia), guayacan (Porlieria angustifolia), catclaw acacia (Acacia greggii), and coma (Bumelia celastrina). Mesquite beans (mast) were a heavily utilized item when available.

Pricklypear cactus (Opuntia lindheimeri) was heavily utilized by this herd of deer during the study. It had the highest percent volume of any species in the diet. Both fruits and pads of pricklypear were utilized. Several individual rumens contained as much as $50-75 \%$ volume of pricklypear.

Comparison of 1970 and 1971 Food Habits

Deer diets did not differ significantly between spring 1970 and spring 1971.
There was, however, a significant difference between percentages of unknown material for the 2 years.

Based on rumen contents of 23 deer collected in spring, 1970, average consumption was $30.3 \%$ browse, $33.0 \%$ forbs, $2.8 \%$ grass, $20.4 \%$ cacti, and $12.5 \%$ unknown. Averages for 39 deer collected in 1971 were $34.8 \%$ browse, $39.4 \%$ forbs, $2.2 \%$ grass, $15.8 \%$ cacti, and $7.5 \%$ unknown.

Forbs were the most preferred food items during both years, but they oc-

Table 2. Overall frequency (\%) of occurrence and volume (\%) of plant species in the diet of white-tailed deer for the spring seasons of 1970 and 1971 on the Randado Ranch in South Texas.

\begin{tabular}{|c|c|c|c|c|c|}
\hline Species or variety & Frequency & Volume & Species or variety & requency & Volume \\
\hline Forbs & & & Grasses & & \\
\hline Acalphya radians Torr. & $T^{1}$ & $\mathrm{~T}$ & Aristida sp. & $\mathrm{T}$ & $\mathbf{T}$ \\
\hline Acanthaceae & 1.6 & 0.02 & Cenchrus ciliaris $\mathrm{L}$. & 4.8 & 0.50 \\
\hline Acleisanthes obtusa (Choisy) Standl. & 6.5 & 0.44 & C. incertus M. A. Curtis & 1.6 & 0.02 \\
\hline Ambrosia psilostachya DC. & 6.5 & 0.76 & Paspalum setaceum Michx. & 1.6 & 0.08 \\
\hline Aphanostephus kidderi Blake & 21.0 & 2.26 & Setaria firmula (Hitch. \& Chase) & 1.6 & 0.10 \\
\hline A. riddellii $\mathrm{T}$. \& $\mathrm{G}$. & 79.0 & 9.55 & 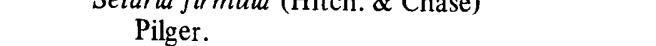 & & \\
\hline Callirhoe involucrata (Torr.) Gray & 24.2 & 2.50 & Unknown grass & 41.9 & 1.71 \\
\hline Cassia texana Buckl. & 8.1 & 0.24 & Unknown grass & 41.9 & 1.11 \\
\hline Cirsium texanum Buckl. & 6.5 & 0.18 & & & \\
\hline Clematis drummondii $\mathrm{T} . \& \mathrm{G}$. & 1.6 & 0.03 & & & \\
\hline Compositae & 9.7 & 0.13 & Browse & & \\
\hline Convolvulus arvensis $\mathrm{L}$ & 6.5 & 0.24 & Acacia berlandieri Benth. & 16.1 & 1.14 \\
\hline Cynanchum barbigerum (Scheele.) Shinner & 12.9 & 0.48 & A. greggii Gray & 43.5 & 2.35 \\
\hline Dalea aurea Nutt. & 33.9 & 1.11 & A. rigidula Benth. & 9.7 & 0.63 \\
\hline Dyssodia tenuiloba (DC.) Robins & 14.5 & 0.53 & A. tortuosa (L.) Willd. & 12.9 & 1.00 \\
\hline Evax verna $\mathrm{Raf}$. & 1.6 & 0.02 & Bumelia celastrina H.B.K. & 29.0 & 2.32 \\
\hline Euphorbia prostrata Ait. & 4.8 & 0.08 & Castella texana (T.\& G.) Rose & 27.4 & 1.24 \\
\hline Gaillardia pulchella Foug. & 1.6 & 0.03 & Celtis pallida Torr. & 50.0 & 3.85 \\
\hline Gaura brachycarpa Small & 19.4 & 1.00 & Cercidium texanum Gray & 3.2 & 0.10 \\
\hline Helianthus annus L. & 6.5 & 0.10 & Colubrina texensis (Torr. \& Gray) Gray & 12.9 & 0.26 \\
\hline Lesquerella gracilis (Hook.) Wats & 12.7 & 0.87 & Condalia hookeri M. C. Johnst. & 6.5 & 0.34 \\
\hline Lepidium sp. & 4.8 & 0.13 & C. obtusifolia (Hook) Weberb & 32.3 & 2.84 \\
\hline Linum imbricatum (Raf.) Shinners & $\begin{array}{l}4.0 \\
T\end{array}$ & $\mathrm{~T}$ & Diospyros texana Scheele $^{2}$ & 9.7 & 1.34 \\
\hline Menodora heterophylla Moric. & 6.5 & 0.45 & Diospyros texana Scheele $^{3}$ & 4.8 & 0.08 \\
\hline Nothoscordum bivalve (L.) Britt. & $\mathrm{T}$ & $\mathrm{T}$ & Ephedra antisyphlitica Berl. & 11.3 & 0.26 \\
\hline Oenothera sp. & 1.6 & 0.66 & Eysenhardtia texana Scheele & 8.1 & 0.55 \\
\hline Palafoxia rosea (Bush) Cory. & 4.8 & 0.18 & Krameria ramosissima (Gray) Wats & 8.1 & 0.18 \\
\hline Parthenium confertum Gray & 35.5 & 2.00 & Leucophyllum frutescens (Berl.) 1. M. Johnst. & 14.5 & 0.35 \\
\hline Petalostemum decumbens Nutt. & 21.0 & $\begin{array}{l}2.00 \\
0.84\end{array}$ & Lycium berlandieri Dun. & 21.0 & 1.10 \\
\hline Phacelia sp. & $\mathrm{T}$ & $\mathrm{T}$ & var. berlandieri & & \\
\hline Phyla incisa Small & 1.6 & 0.03 & L. carolinianum Walt. var. & 3.2 & 0.05 \\
\hline Physalis visoca L. var. & 30.6 & 2.97 & quadrifidum (Dun.) C. L. Hitchc. & & \\
\hline cinerascens (Dun.) Waterfall & & & Porlieria angustifolia (Engelm.) Gray & 29.0 & 2.50 \\
\hline Plantago hookeriana Fisch. \& Mey & 9.7 & 0.45 & Prosopis glandulosa Torr. & 17.7 & 8.77 \\
\hline Polygonaceae & 1.6 & 0.03 & P. glandulosa Torr. & $12.9^{2}$ & 0.16 \\
\hline Portulaca mundula I. M. Johnst. & $\mathrm{T}$ & $\mathrm{T}$ & $P$. reptans Benth. var. & $\mathrm{T}$ & $\mathrm{T}$ \\
\hline Psilostrophe gnaphalodes DC. & 30.6 & 1.10 & cinearascens (Gray) Burk & & \\
\hline Pyrrhopappus multicaulis DC. & 1.6 & 0.02 & Schaefferia cuneifolia Gray & 29.0 & 0.63 \\
\hline Ratibida columnaris (Sims) D. Don & 3.2 & 0.08 & Xanthocephalum sarothrae (Pursh.) & & \\
\hline Rhynchosia americana (Mill.) C. Metz. & 8.1 & 0.18 & Shinners & $T$ & $\mathrm{~T}$ \\
\hline Rumex crispus $\mathrm{L}$. & 1.6 & 0.02 & Yucca treculeana Carr. & 3.2 & 0.08 \\
\hline Schrankia latidens (Small) K. Schum. & 14.5 & 0.27 & Zanthoxylum fagara Sarg. & 17.7 & 0.58 \\
\hline Sida filicaulis T. \& G. & 8.1 & 0.31 & Unknown browse & 24.2 & 0.42 \\
\hline Solanaceae & 1.5 & 0.08 & & & \\
\hline Sphaeralcea pedatifida Gray & 9.7 & 0.65 & & & \\
\hline Thelesperma sp. & 16.1 & 1.06 & Cacti Onuntia lentocaulis DC & & \\
\hline Verbena sp. & 1.6 & 0.03 & Opuntia leptocaulis DC. & 22.6 & 2.08 \\
\hline Verbena plicata Greene & 8.1 & 0.58 & $\begin{array}{l}\text { O. lindheimeri Engelm. var. } \\
\text { tricolor (Griffiths) L. Benson }{ }^{3}\end{array}$ & 56.5 & 8.68 \\
\hline Vicia leavenworthii T.\& G. & 1.6 & 0.02 & $\begin{array}{l}\text { tricolor (Griftiths) L. Benson } \\
O \text { lindheimeri Engelm }\end{array}$ & 290 & 674 \\
\hline Zexmenia hispida (H.B.K.) Gray & 3.2 & 0.11 & O. lindhetmerl Engelm ${ }^{2}$ & 29.0 & 6.74 \\
\hline Zornia bracteata J. F. Gmel. & 8.1 & 0.29 & & & \\
\hline Unknown forbs & 77.4 & 4.31 & Unknown material & 100.0 & 9.40 \\
\hline
\end{tabular}

\footnotetext{
Trace, observed in rumen sample but not recorded as a direct hit.
} ${ }^{3}$ Vegetative. 
curred at a slightly higher percentage in 1971. Perennial lazy daisy was the most prevalent forb in the diet both years, but winecup occurred in considerably higher volume in 1971.

Browse was found in slightly larger amounts in the 1971 diet than in 1970. A number of differences were found in the browse species consumed between the 2 years. Differences were also found in the percent volume which these species contributed to the diet. Mexican persimmon (Diospyros texana) mast was a major constituent in the 1970 diet, when it comprised $3.6 \%$ volume, but it did not occur in the 1971 diet. Mesquite mast contributed a large volume in both years, but was consumed in larger amounts in 1971 when it occurred at $10.7 \%$ volume as compared to $5.5 \%$ in 1970 . Catclaw acacia accounted for $3.5 \%$ volume of the 1971 diet, but was utilized considerably less in 1970 when it comprised only $0.8 \%$ volume. Other woody species such as granjeno, guayacan, coma, and lotebush comprised large percent volumes both years.

Cacti occurred in higher volume in the 1970 diet than in 1971. This difference was attributed to the higher rate of occurrence of pricklypear mast in the 1970 diet. Tasajillo (Opuntia leptocaulis) was of equal importance during both years.

Grass was not utilized in large amounts in either year, as its percent volume was $2.8 \%$ in 1970 and $2.2 \%$ in 1971 .

\section{Early Spring vs Late Spring}

In comparing deer food habits between early and late spring over both years, some major differences were found. The early spring diet was based on analyses of 25 rumens. Average percent volume for early spring was $23.2 \%$ browse, $51.5 \%$ forbs, $2.3 \%$ grass, $12.9 \%$ cacti, and 9.6\% unknown. Late spring diet was determined from analyses of 37 rumens. Percentage volume for the major forage classes was $39.6 \%$ browse, $27.5 \%$ forbs, $2.6 \%$ grass, $20.6 \%$ cacti, and $9.2 \%$ unknown.

There was a significant difference in the percentage of forbs consumed between early and late spring. Forbs were the most important item in early spring. In late spring, however, with the development of mesquite beans and pricklypear mast, there was a shift away from forbs. Perennial lazy daisy comprised over $12 \%$ of the early spring diet. Annual lazy daisy (Aphanostephus kidderi) was also widely utilized, comprising $4.8 \%$ volume of the diet. Other important forbs in early spring were golden dalea (Dalea aurea), western ragweed, (Ambrosia psilostachya), bladderpod (Lesquerella gracilis), wild honeysuckle (Gaura brachycarpa), thelesperma (Thelesperma sp.), groundcherry, and winecup. With lower total consumption of forbs in late spring

Table 3. Frequency $(\%)$ of occurrence, volume (\%), availability, and preference of major forage plants utilized by white-tailed deer on the sandy loam range site of the Randado Ranch in South Texas during the spring seasons 1970 and 1971.

\begin{tabular}{|c|c|c|c|c|}
\hline Species & Frequency ${ }^{1}$ & Volume $^{2}$ & $\begin{array}{c}\text { Availability } \\
\text { factor }^{3}\end{array}$ & $\begin{array}{c}\text { Preference } \\
\text { rating }\end{array}$ \\
\hline \multicolumn{5}{|l|}{ Forbs } \\
\hline Aphanostephus riddellii & 73 & 10.2 & 3 & 248 \\
\hline A. kidderi & 24 & 2.4 & 1 & 58 \\
\hline Callirhoe involucrata & 36 & 3.9 & 3 & 47 \\
\hline Dalea aurea & 49 & 1.6 & 1 & 78 \\
\hline Gaura brachycarpa & 27 & 1.4 & 1 & 38 \\
\hline Parthenium confertum & 33 & 2.0 & 3 & 22 \\
\hline Petalostemum decumbens & 27 & 1.2 & 1 & 32 \\
\hline Physalis viscosa & 30 & 4.2 & 3 & 42 \\
\hline Psilostrophe gnaphalodes & 33 & 1.5 & 1 & 50 \\
\hline Thelesperma sp. & 24 & 2.0 & 1 & 48 \\
\hline \multicolumn{5}{|l|}{ Browse } \\
\hline Acacia greggii & 49 & 3.2 & 2 & 79 \\
\hline Bumelia celastrina & 27 & 2.0 & 1 & 54 \\
\hline Castela texana & 24 & 1.3 & 2 & 16 \\
\hline Celtis pallida & 42 & 3.6 & 2 & 76 \\
\hline Condalia obtusifolia & 30 & 3.1 & 2 & 47 \\
\hline Lycium berlandieri & 24 & 1.5 & 1 & 36 \\
\hline Prosopis glandulosa ${ }^{5}$ & 16 & 8.3 & 3 & 44 \\
\hline Zanthoxylum fagara & 30 & 1.0 & 1 & 30 \\
\hline \multicolumn{5}{|l|}{ Cacti } \\
\hline Opuntia leptocaulis & 18 & 1.6 & 1 & 29 \\
\hline O. lindheimeri ${ }^{6}$ & 52 & 7.6 & 1 & 395 \\
\hline O. lindheimeri ${ }^{5}$ & 33 & 5.5 & 1 & 182 \\
\hline
\end{tabular}

${ }^{1}$ Frequency of occurrence in 33 rumens.

${ }^{2}$ Percent volume $=$ Number point hits per species $\div$ Total number sampling points in 33 rumens.

${ }^{3}$ Availability factor: rare $=1$, occasional $=2$, frequent $=3$, abundant $=4$.

${ }^{4}$ Preverence rating $=(\%$ frequency of occurrence $\times \%$ volume $) \div$ availability factor

${ }^{5}$ Mast.

${ }^{6}$ Vegetative.

Table 4. Frequency (\%) of occurrence, volume (\%), availability, and preference of major forage plants utilized by white-tailed deer on the Ramadero range site of the Randado Ranch in South Texas during the spring seasons of 1970 and 1971.

\begin{tabular}{|c|c|c|c|c|}
\hline Species & Frequency $^{1}$ & Volume $^{2}$ & $\begin{array}{l}\text { Availability } \\
\text { factor }^{3}\end{array}$ & $\begin{array}{l}\text { Preference } \\
\text { rating }\end{array}$ \\
\hline \multicolumn{5}{|l|}{ Forbs } \\
\hline Ambrosia psilostachya & 27 & 3.1 & 3 & 28 \\
\hline Aphanostephus riddellii & 87 & 10.4 & 3 & 302 \\
\hline A. kidderi & 27 & 4.0 & 1 & 108 \\
\hline Callirhoe involucrata & 20 & 1.7 & 1 & 34 \\
\hline Parthenium confertum & 33 & 0.9 & 3 & 10 \\
\hline Physalis viscosa & 33 & 3.5 & 2 & 58 \\
\hline \multicolumn{5}{|l|}{ Browse } \\
\hline A cacia greggii & 53 & 2.1 & 1 & 111 \\
\hline Celtis pallida & 60 & 5.3 & 3 & 106 \\
\hline Condalia obtusifolia & 40 & 1.6 & 1 & 64 \\
\hline Diospyros texana ${ }^{5}$ & 20 & 3.5 & 2 & 35 \\
\hline Porlieria angustifolia & 53 & 2.7 & 2 & 72 \\
\hline Prosopis glandulosa ${ }^{5}$ & 27 & 12.4 & 4 & 84 \\
\hline \multicolumn{5}{|l|}{ Cacti } \\
\hline Opuntia leptocaulis & 33 & 2.7 & 1 & 89 \\
\hline$O$. lindheimeri $^{6}$ & 67 & 8.1 & 1 & 543 \\
\hline O. lindheimeri ${ }^{5}$ & 27 & 6.6 & 1 & 178 \\
\hline
\end{tabular}

\footnotetext{
${ }^{1}$ Frequency of occurrence in 15 rumens.

${ }^{2}$ Percent volume $=$ Number point hits per species $\div$ Total number sampling points in 15 rumens.

${ }^{3}$ Availability factor: rare $=1$, occasional $=2$, frequent $=3$, abundant $=4$.

${ }^{4}$ Preference rating $=(\%$ frequency of occurrence $\times \%$ volume $) \div$ availability factor

${ }^{5}$ Mast.

${ }^{6}$ Vegetative.
} 


\section{fertum) and winecup.}

There was a significant difference in the percentage of browse consumed between early and late spring. The most preferred browse species in early spring was granjeno, which comprised $4.4 \%$ volume. Catclaw, coma, and guayacan were other browse species heavily consumed in early spring. The increase in use of browse in late spring was attributed to the abundance of mesquite mast. This one species provided $14.7 \%$ of the late spring diet and occurred in high volume in a number of individual rumens. Mesquite leaves and stem tips were utilized very little. Mexican persimmon mast also contributed to this increase, as it comprised $2.2 \%$ of the late spring diet. Lotebush was significant in late spring, comprising $4.0 \%$ volume. Other browse species which comprised significant portions of the late spring diet were allthorn goatbush (Castela texana), granjeno, catclaw, guayacan, and coma.

Cacti were important in the early spring diet when this class comprised $12.9 \%$ volume. They became increasingly important in late spring with the development of pricklypear mast when it contributed $20.6 \%$ to the total diet. There was a significant increase in the percentage of cacti from early to late spring diet.

Grass was of little importance in either early or late spring, comprising only $2.3 \%$ and $2.6 \%$ volume, respectively. There was no significant difference between these percentages.

The percentages of unknown material for the two periods were not significantly different.

\section{Sandy Loam Site}

Thirty-three deer were collected from the sandy loam range site. Their diet consisted of 71 different plant taxa, including 42 forbs, 23 browse species, 4 grasses, and 2 cacti. Forbs contributed an average of $43.3 \%$ volume to the diet, browse $30.8 \%$, cacti $14.6 \%$, grass $2.1 \%$, and unknown $9.1 \%$. Percentages of browse and forbs were significantly higher than the other classes.

Twenty species comprised $68.7 \%$ of the diet on this site (Table 3). These included 10 forbs, 8 browse species, and 2 cacti.

\section{Ramadero Site}

Browse and forbs were the most preferred deer foods from the Ramadero site. Of 15 deer collected from this site, $35.2 \%$ volume of their diet consisted of forbs, while $34.1 \%$ was browse. These two classes were significantly higher than
Table 5. Frequency $(\%)$ of occurrence, volume $(\%)$, availability, and preference of major forage plants utilized by white-tailed deer on the shallow ridge range site of the Randado Ranch in South Texas during the spring seasons of 1970 and 1971.

\begin{tabular}{|c|c|c|c|c|}
\hline Species & Frequency ${ }^{1}$ & Volume $^{2}$ & $\begin{array}{l}\text { Availability } \\
\text { factor }^{3}\end{array}$ & $\begin{array}{c}\text { Preference } \\
\text { rating }^{4}\end{array}$ \\
\hline \multicolumn{5}{|l|}{ Forbs } \\
\hline Acleisanthes obtusa & 14 & 1.6 & 1 & 22 \\
\hline Aphanostephus riddellii & 86 & 7.4 & 4 & 159 \\
\hline Dyssodia tenuiloba & 21 & 1.0 & 2 & 11 \\
\hline Lesquerella sp. & 21 & 1.8 & 1 & 38 \\
\hline Parthenium confertum & 43 & 3.1 & 4 & 33 \\
\hline \multicolumn{5}{|l|}{ Browse } \\
\hline Acacia berlandieri & 50 & 4.8 & 4 & 60 \\
\hline Bumelia celastrina & 71 & 5.5 & 1 & 391 \\
\hline Celtis pallida & 57 & 3.0 & 1 & 171 \\
\hline Condalia obtusifolia & 36 & 4.1 & 1 & 148 \\
\hline Porlieria angustifolia & 57 & 6.9 & 2 & 197 \\
\hline Proso pis glandulosa ${ }^{5}$ & 14 & 6.0 & 1 & 84 \\
\hline \multicolumn{5}{|l|}{ Cacti } \\
\hline Opuntia leptocaulis & 21 & 2.7 & 1 & 57 \\
\hline O. lindheimeri ${ }^{6}$ & 50 & 10.9 & 1 & 545 \\
\hline O. lindheimer $i^{5}$ & 29 & 10.7 & 1 & 310 \\
\hline
\end{tabular}

${ }^{1}$ Frequency of occurrence in 14 rumens.

${ }^{2}$ Percent volume $=$ Number point hits per species $\div$ Total number sampling points in 14 rumens.

${ }^{3}$ Availability factor: rare $=1$, occasional $=2$, frequent $=3$, abundant $=4$.

${ }^{4}$ Preference rating $=(\%$ frequency of occurrence $\times \%$ volume $) \div$ availability factor.

${ }^{5}$ Mast.

${ }^{6}$ Vegetative.

the other classes. Cacti were of secondary importance, contributing $17.5 \%$ to the diet, while grass comprised $2.9 \%$. The portion unidentifiable to forage class was $10.3 \%$.

Fifty-two different plant taxa were identified in the diet from the Ramadero site. Forbs contributed nearly two-thirds of these with a total of 29 taxa. There were 20 browse, 2 cacti, and 1 grass taxa.

A total of 14 species comprised $68.5 \%$ of the diet on this site (Table 4). Twelve of these were perennials, while two were annuals.

\section{Shallow Ridge Site}

The diet of 14 deer from the shallow ridge site contained 47 plant taxa, including 24 forbs, 20 browse, 2 cacti, and 1 grass. Browse was the most important item in the diet, comprising $38.8 \%$ of the total volume, cacti $24.6 \%$, forbs $24.3 \%$, and grass $2.9 \%$. Approximately $9.4 \%$ was unidentifiable to forage class.

Browse was significantly higher than the other classes. Thirteen different plant taxa contributed $69.4 \%$ volume to the diet (Table 5). Of these, 10 were perennials and 3 were annuals.

\section{Summary and Conclusion}

Due to the mosaic pattern of the soil types on the ranch, many of the same plant taxa occurred in deer diets from all three range sites. Ten species contributed a major percent volume to the diet. These were perennial lazy daisy, groundcherry, winecup, granjeno, lotebush, mesquite, guayacan, catclaw acacia, coma, and pricklypear cactus.

A total of 83 plant taxa were found to be eaten by white-tailed deer on the Zachry ranch. Perennials were more sought after than annuals. Spring food habits of the white-tailed deer were dependent on availability of vegetation, but were also influenced by individual deer preferences.

It should be apparent from the data presented in this study that managers should strive for a good intermixture of vegetative types if they want to provide good deer habitat. Forbs are a very important part of the diet of white-tails, but browse species must be provided for both food and cover.

\section{Literature Cited}

Atwood, E. L. 1941. White-tailed deer food habits of the United States. J. Wildl. Manage. 5:34-332.

Canfield, R. H. 1941. Application of the line interception method in range vegetation. $J$. Forest. 39:388-394.

Chamrad, A. D., and T. W. Box. 1964. A point frame for sampling rumen contents. J. Wildl. Manage. 28:473-477.

Chamrad, A. D., and T. W. Box. 1968. Food habits of white-tailed deer in South Texas. J. Range Manage. 21:158-164.

Correll, D. S., and M. C. Johnston. 1970. Manual of the vascular plant of Texas. Tex. Res. Found., Renner, Texas 1881 p.

Dallas Morning News, The. 1970-1971. The Texas Almanac. Dallas. $704 \mathrm{p}$.

Davis, R. B. 1951. The food habits of whitetailed deer on the cattle stocked, liveoakmesquite ranges of the King Ranch, as determined by analysis of deer rumen contents. MS Thesis. Texas A\&M College, College Station. $97 \mathrm{p}$.

Davis, R. B., and C. K. Winkler. 1968. Brush vs. cleared range as deer habitat in southern 
Texas. J. Wildl. Manage. 32:321-329.

Drawe, D. L. 1968. Mid-summer diet of deer on the Welder Wildlife Refuge. J. Range Manage. 21:164-166.

Gould, F. W. 1969. Texas plants - A checklist and ecological summary. Tex. Agr. Exp. Sta. Texas A\&M Univ., College Station. M P $385.121 \mathrm{p}$.

Hahn, H. C., Jr. 1945. The white-tailed deer in the Edwards Plateau region of Texas. Bull. Tex. Game, Fish, and Oyster Comm. 52 p.
Higginbotham, Ira, Jr. 1972. Vegetative composition and productivity of four range sites on the Zachry Randado Ranch in South Texas. Unpub. Prog. Rep., School of Agr., Texas A\&I Univ., Kingsville. 12 p.

Kelley, J. A. 1970. Food habits of four exotic big-game animals on a Texas "Hill Country" ranch. MS Thesis. Texas A\&I U., Kingsville. $101 \mathrm{p}$.

McMahan, C. A. 1964. Comparative food habits of deer and three classes of livestock. J. Wildl. Manage. 28:798-808.
Ramsey, C. W. 1965. Potential economic return from deer as compared with livestock in the Edwards Plateau Region of Texas. J. Range Manage. 18:247-250.

Tothill, J. C., and M. L. Peterson. 1962. Botanical Analysis and Sampling: Tame Pastures. p. 109-134. In Pasture and Range Research Techniques. Comstock Publ. Ass., Ithaca, N.Y. 242 p.

Vestal, A. G. 1943. Unequal scales for rating species in communities. Amer. J. Bot. 31:305-310. 